\title{
LOKALIZACJA JAKO CZYNNIK WPŁYWAJACCY NA DECYZJE ZAKUPOWE KLIENTÓW NA PRZYKŁADZIE TORUŃSKICH HIPERMARKETÓW REAL I CARREFOUR
}

Z a ry s treś c i. W artykule przedstawiono wybrane aspekty lokalizacji obiektów handlowych. Omówiono istotę oraz instrumenty lokalizacji. Wskazano znaczenie lokalizacji obiektów, która wpływa na decyzje zakupowe konsumentów. Przedstawiono wyniki badania ankietowego, którego celem było określenie czynników determinujących wybór wybranych hipermarketów jako miejsc realizacji zakupów.

Słow a kluc z owe : lokalizacja, decyzje zakupowe konsumentów, hipermarkety.

\section{WSTĘP}

Przyglądając się wszystkim problemom ekonomicznym i organizacyjnym związanym z kształtowaniem sieci handlowej, dochodzimy do wniosku, że największe znaczenie ma lokalizacja. Powszechne jest potoczne stwierdzenie, że o sukcesie handlowym punktu sprzedaży detalicznej przesądzają trzy czynniki: lokalizacja, lokalizacja i lokalizacja. Można być najlepszym detalistą na świecie, lecz jeżeli ulokuje się obiekt w złym miejscu, to nigdy wiele się nie zdziała (Sullivan, Adcock, 2003). Lokalizacja wpływa na sukces bądź niepowodzenie danego obiektu handlowego. Zauważa się, że co najmniej $85 \%$ wyników danego sklepu nie jest determinowanych wewnętrzną kontrolą kierownictwa, lecz czynnikami lokalnymi i zewnętrznymi. Warto zatem przyjrzeć się bliżej pojęciu lokalizacji oraz wpływie, jaki wywiera na decyzje zakupowe klientów. 


\section{ISTOTA I INSTRUMENTY LOKALIZACJI}

Przyczyny ogromnego znaczenia lokalizacji placówki detalicznej leżą w samej naturze handlu detalicznego i jego otoczenia. Jest on bowiem działalnością gospodarczą opierającą się na ruchu, czyli na stałym napływie potencjalnych klientów do sklepu. Im dogodniejsze jest umiejscowienie sklepu, tym większe jest prawdopodobieństwo, że nabywcy go odwiedzą. Należy spojrzeć również z drugiej strony - nabywcy będą mieli słabsze motywy do odwiedzenia sklepu, jeśli będzie to dla nich trudne ze względu na dużą odległość od domu (czy też miejsca pracy) lub złe połączenie komunikacyjne.

Znaczenie lokalizacji dla zapewnienia sukcesu działalności jest tak wielkie, że większość detalistów umieszcza ją na pierwszym miejscu listy zagadnień taktycznych. Jeżeli wybierze się optymalną lokalizację, to reszta może przyjść już sama. Jeżeli natomiast wybierze się lokalizację niedogodną, to można oczekiwać, że wyniki sklepu będą słabe - niezależnie od innych elementów taktycznych. Każda bowiem jednostka handlowa ma określone miejsce w przestrzeni i nie można jej z reguły przenieść, można jedynie zmienić branżę i oferowany w niej asortyment. Istotą zatem lokalizacji sieci handlowej jest jej stosunek do zajmowanej powierzchni. Jest on długookresowy i trwały w przypadku sklepów lub okresowy w przypadku kiosków czy straganów, a podjęte decyzje pociągają za sobą długoletnie konsekwencje (Sławińska, 1989).

Należy zauważyć, że na wybór lokalizacji mają również wpływ inne czynniki aniżeli interesy nabywców i detalistów. Istotnym elementem jest polityka władz różnych szczebli, które w ramach działań optymalizujących funkcjonowania całego regionu wpływają pośrednio na rozwój i kształt sieci (Szulce, 1998).

Decyzje dotyczące lokalizacji podejmowane są dwustopniowo. W pierwszej fazie wyznacza się lokalizację ogólną, która zdeterminowana jest głównie wspomnianymi wyżej uwarunkowaniami oraz skalą zapotrzebowania na usługi handlu, czyli określoną przestrzenią handlową. W drugiej natomiast określa się zasady wyboru konkretnego miejsca, w którym dany obiekt handlowy powinien stanąć - wyznacza się więc lokalizację szczegółową. Czasami zdarza się, że handlowiec zainteresowany jest wyłącznie lokalizacją szczegółową - przyjmuje on bowiem z góry jako wyznacznik nadrzędny określoną przestrzeń handlową, z reguły tę, w której działał dotychczas. Przejdźmy zatem do głębszej analizy pojęcia lokalizacji ogólnej i szczegółowej. 


\subsection{LOKALIZACJA OGÓLNA}

Zagadnienie lokalizacji ogólnej sprowadza się do przeprowadzenia ogólnego zestawienia sieci handlowo-usługowej istniejącej na danym terenie z zapotrzebowaniem na tę sieć. Należy zatem podjąć się następujących zadań (Drewiński, 1983):

- ustalenia zapotrzebowania (rozmiarów sieci) dostosowanego do efektywnego popytu,

- podziału tego zapotrzebowania na typy asortymentowe,

- ustalenia rodzaju i liczby szczebli lokalizacji,

- ustalenia rozmiarów sieci (według struktury branżowej) odpowiednio do szczebli lokalizacji,

- ostatecznego zbilansowania popytu realizowanego na danym obszarze z przepustowością oraz przelotowością istniejącej i planowanej sieci.

Wyznaczenie lokalizacji ogólnej powinno się więc rozpocząć od określenia potencjalnej przestrzeni rynkowej (Szulce, 1998). Oznacza to, iż niezbędne jest określenie pewnego obszaru gospodarczego, z którego dany obiekt handlowy będzie przyciągał klientów. Przedsiębiorca będzie więc poszukiwał takiej przestrzeni rynkowej, jaka umożliwi mu osiąganie określonej wielkości obrotów i marż, biorąc pod uwagę istniejącą konkurencję, regionalne obyczaje, trendy oraz zachowania nabywców, a także związane z zagospodarowaniem regionu decyzje władz różnych szczebli.

Ten rodzaj lokalizacji zależny jest przede wszystkim od liczby ludności i jej efektywnego zapotrzebowania na określoną wielkość i strukturę masy towarowej. Lokalizacja ogólna determinowana jest również przez czynniki funkcjonalno-przestrzenne oraz czynniki wyznaczające efektywność sieci detalicznej. Do powszechnie uwzględnianych determinant zalicza się liczbę i strukturę ludności. Popularność tego rodzaju lokalizacji powiązana jest ze względną łatwością ustalenia wielkości zaludnienia oraz niewielką zmiennością tego czynnika w średnich i krótkich okresach danej przestrzeni. Błędne jest wnioskowanie na podstawie informacji o stałych mieszkańcach i pomijanie zamiejscowych klientów. Liczbę tych ostatnich należy oszacować, biorąc pod uwagę infrastrukturę transportową i układ komunikacyjny regionu. Istotne jest także dokonanie analizy zwyczajów potencjalnych konsumentów, identyfikacji miejsca oraz przyczyn dokonywania zakupów, odległości, którą skłonni są pokonywać klienci, preferencji dotyczących lokalizacji sklepów, form obsługi, metod płatności itp.

Kolejna grupa czynników dotyczy wyznaczników efektywnego popytu. Jest ona związana $\mathrm{z}$ wielkością i strukturą dochodów, transferem siły nabywczej oraz przestrzennym zróżnicowaniem cen i zróżnicowaniem asortymentu towarów. 
Przy wyznaczeniu przestrzeni handlowej ważne jest określenie dyspozycyjnego dochodu osobistego, czyli funduszy, którymi dysponują konsumenci, po poniesieniu niezbędnych wydatków (odpowiadających kosztom utrzymania) oraz zapłaceniu podatków. Zmiany zachodzące w tej części wydatków wpływają na obroty dobrami trwałymi, w szczególności tymi, których ceny są relatywnie wysokie, w związku z czym zakup jest z reguły uprzednio planowany. Na podstawie obserwacji można wnioskować, że fundusz ten jest wyższy i bardziej stabilny w przestrzeniach, w których rozwinięte są różne gałęzie przemysłu i działalności gospodarczej, niż tam, gdzie dominuje tylko jedna gałąź przemysłu.

Następną grupę stanowią czynniki funkcjonalno-przestrzenne, do których zaliczyć można strukturę sieci osadniczej, stopień zurbanizowania terenu, związaną z tym wielkość i atrakcyjność ośrodka handlowego traktowanego jako skupisko handlu oraz istniejący układ komunikacyjny.

Przestrzeń handlową danego obszaru wyznaczają zatem następujące determinanty: liczba i struktura ludności, efektywny popyt, struktura sieci osadniczej, stopień zurbanizowania terenu, infrastruktura transportowa, wielkość ośrodka handlowego. Jest ona zróżnicowana w zależności od rodzaju sprzedawanych produktów oraz częstotliwości ich zakupu.

Walka konkurencyjna $\mathrm{w}$ handlu toczy się $\mathrm{w}$ dużej mierze o przyciąganie nabywców spoza naturalnego regionu obsługi. Musi więc nastąpić takie zwiększenie przestrzeni handlowej, aby obejmowała ona coraz większy geograficznie rynek. Konkurencja istotnie wpływa na lokalizację. Jednakże decyzje zmierzające do monopolistycznej lokalizacji w danej przestrzeni handlowej, nie zawsze są wskazane. Zasadniczo okazują się one efektywne tylko w przypadku niektórych sklepów o specjalnym charakterze.

W przypadku chęci podjęcia decyzji dotyczącej wyboru kraju należy przeprowadzić audyt zewnętrznych czynników marketingowych, podczas którego analityk stara się wykryć wszystkie czynniki mogące pozytywnie lub negatywnie wpłynąć na atrakcyjność danego kraju (Sullivan, Adcock, 2003). Następnie przeprowadza się porównawczą ocenę rozważanych obszarów, stosując metodę sekwencji progów lub metodę wieloczynnikową. Pierwsza z nich polega na wyodrębnieniu czynników najistotniejszych dla przedsiębiorstwa - takich jak poziom wydatków klientów, osobisty rozporządzalny dochód, nasilenie konkurencji, dostępność lokalizacji, przepisy dotyczące planowania przestrzennego oraz uszeregowaniu listy krajów na ich podstawie. Następnie wyznacza się minimalne wartości poszczególnych czynników, aby w dalszej - dokładniejszej analizie uwzględnić tylko te kraje, które pod względem wszystkich kryteriów przekraczają wymagany poziom. Metoda wieloczynnikowa natomiast polega na ocenie wszystkich krajów ze względu na pewne czynniki analogiczne do tych, które stosuje się w metodzie sekwencji progów. Każdemu czynnikowi przypisuje się 
wagę odzwierciedlającą jego znaczenie dla przedsiębiorstwa. Następnie oblicza się ogólną punktację każdego kraju, mnożąc ją w zakresie poszczególnych czynników przez wagi i sumując wyniki. Przez tę wstępną selekcję przechodzą kraje, które uzyskały określone minimum punktów i tylko one są poddawane dalszej ocenie. W tabeli 1 przedstawiono przykłady wykorzystania wymienionych metod. Po dokonaniu wstępnej selekcji kraju należy przeprowadzić wstępny wybór regionów w zaakceptowanych krajach. Przebiega ona zasadniczo w ten sam sposób jak w przypadku krajów, lecz wykorzystuje się w niej znacznie bardziej szczegółowe dane lokalne.

Tabela 1. Przykłady oceny metodą sekwencji progów i metodą wieloczynnikową

\begin{tabular}{|c|c|c|c|c|}
\hline \multicolumn{5}{|c|}{ Dla krajów A, B, C, D i E uzyskane następujące dane: } \\
\hline kraj & rozwój rynku & poziom konkurencji & $\begin{array}{c}\text { dostępność } \\
\text { lokalizacji }\end{array}$ & $\begin{array}{c}\text { osobisty } \\
\text { dochód rozporządzalny }\end{array}$ \\
\hline A & 4 & 3 & 9 & 3 \\
\hline B & 5 & 4 & 4 & 6 \\
\hline C & 8 & 6 & 4 & 7 \\
\hline D & 6 & 5 & 6 & 6 \\
\hline E & 2 & 3 & 7 & 2 \\
\hline
\end{tabular}

\begin{tabular}{|l|c|c|c|c|}
\hline \multicolumn{5}{|c|}{ Detalista określa wagi i wymagane minima w następujący sposób: } \\
\hline & rozwój rynku & poziom konkurencji & $\begin{array}{c}\text { dostępność } \\
\text { lokalizacji }\end{array}$ & $\begin{array}{c}\text { osobisty dochód } \\
\text { rozporządzalny }\end{array}$ \\
\hline Waga & 3 & 5 & 7 & 8 \\
\hline Wymagane min & 3 & 4 & 6 & 6 \\
\hline
\end{tabular}

\begin{tabular}{|c|c|}
\hline & Ocena metodą sekwencji progów \\
\hline $\begin{array}{l}\text { Próg } 1 \\
\text { Próg } 2 \\
\text { Próg } 3\end{array}$ & $\begin{array}{l}\text { (poziom osobistego dochodu rozporządzalnego) - wykluczony kraj E } \\
\text { (wynik poniżej minimum) } \\
\text { (dosteppność lokalizacji) - wykluczone kraje B i C } \\
\text { (poziom konkurencji) - wykluczony kraj A }\end{array}$ \\
\hline \multicolumn{2}{|c|}{ Wynik- zaakceptowany zostaje kraj D } \\
\hline \multicolumn{2}{|c|}{ Ocena metodą wieloczynnikową } \\
\hline \multicolumn{2}{|c|}{$\begin{array}{l}\text { Łączny wynik kraju } A=114(4 \times 3+3 \times 5+9 \times 7+3 \times 8) \\
\text { tączny wynik kraju } B=111(5 \times 3+4 \times 5+4 \times 7+6 \times 8) \\
\text { tączny wynik kraju } C=138(8 \times 3+6 \times 5+4 \times 7+7 \times 8) \\
\text { tacczny wynik kraju } D=133(6 \times 3+5 \times 5+6 \times 7+6 \times 8) \\
\text { tączny wynik kraju } E=86(3 \times 3+4 \times 5+6 \times 7+6 \times 8)\end{array}$} \\
\hline Wynik - & \\
\hline
\end{tabular}

Źródło: opracowanie własne na podstawie Sullivan, Adcock, 2003. 


\subsection{LOKALIZACJA SZCZEGÓŁOWA}

Ten rodzaj lokalizacji wiąże się ściśle z przestrzenną strukturą handlu, tzn. rodzajem zabudowy, występowaniem dzielnic o określonych funkcjach społeczno-gospodarczych, ciągami ulic itp. (Szulce, 1998). Lista czynników wyznaczających lokalizację szczegółową jest zmienna - mają na nią wpływ tendencje występujące w rozwoju modelu sieci handlowej. Prawidłowości te wiążą się z obserwowalną niewydolnością centrów miast jako centrów handlowych o zasięgu ogólnomiejskim. Determinuje to (przy wzrastającej skłonności do rzadszych, ale większych zakupów) lokalizację obiektów handlowych, oferujących asortyment towarów nabywanych w zakupach bezproblemowych, poza obszarem centrum, gdyż tylko tam można zapewnić dostatecznie dużo miejsc parkingowych. Zjawiskiem niejako wspierającym tę tendencję jest intensywny rozwój przestrzenny miast powstają nowe osiedla, następuje rozwój terenów podmiejskich (nazywanych sypialniami wielkich miast). Zjawiska te mają wpływ na konieczność lokalizacji centrów handlowych na zewnątrz zespołów staromiejskich, a często nawet poza granicami miasta.

Wśród najczęściej wymienianych czynników w zakresie lokalizacji szczegółowej, wpływających na sukces handlu, wymienia się: kompatybilność, dostosowanie miejsca i budynku do przyjętych założeń działania, dostępność sklepów, parkingi, dostrzegalność handlu, cenę dzierżawy lub alternatywną cenę kupna danego obiektu, natężenie i kierunek ruchu, konkurencję, dotychczasowy wizerunek obiektów handlowych zlokalizowanych w analizowanym miejscu (Knee, Waters, 1985; Szulce 1998).

Kompatybilność łączy się z relacjami zachodzącymi między jednostką handlową a pozostałą siecią zlokalizowaną na danym obszarze. Jeżeli dwoje sąsiadujących ze sobą kupców sprzedaje większą ilość towarów, działając obok siebie, niż wtedy, gdy byli od siebie odseparowani, to spełniają warunek kompatybilności. Jest to związane z ideą łącznego zaspokajania potrzeb zgłaszanych przez dany segment na tym samym obszarze. Podczas podejmowania decyzji dotyczących lokalizacji należy więc rozstrzygnąć, czy znajdujące się w pobliżu sklepy pomagają w osiąganiu danej wielkości sprzedaży nowej jednostki handlowej, czy też nie.

$\mathrm{Z}$ tego punktu widzenia można dokonać następującego podziału sklepów:

- tzw. handel generujący, który bezpośrednio przyciąga klientów,

- handel wspólny, który przyciąga klientów łącznie z innymi sklepami znajdującymi się w podobnej sytuacji pod względem sprzedaży,

- handel przyciągający klientów w sytuacjach, gdy zakupy są uboczne, przypadkowe, tak jak np. w sklepach na lotniskach. 
Równie istotne jest dostosowanie miejsca, kształtu oraz rodzaju budynku. Należy rozważyć dostępność obiektu, konieczność remontu, możliwości parkowania, istnienie podjazdów itp.

Duże znaczenie ma lokalizacja sklepów przy popularnych trasach dla pieszych (np. w pobliżu przystanków komunikacji miejskiej czy parkingów). Jest to powiązane z zagadnieniem dostępności obiektu (wyznaczoną np. trudnością przejścia na drugą stronę ulicy). Istotna jest również strona ulicy, na której zlokalizowany jest sklep. Przykładowo - dwie strony ulicy, którymi przechodzą ludzie będący potencjalnymi klientami z pracy i do pracy, mają z reguły inny charakter. Pewne produkty kupowane są częściej w drodze do pracy (gazety, śniadanie, kawa), a inne w drodze do domu.

Kolejnym wyznacznikiem szczegółowej lokalizacji jest konkurencja. Jak wspomniano wcześniej, silna, bezpośrednia konkurencja w pobliżu działania placówki handlowej dla niektórych branż może okazać się szkodliwa, a dla innych korzystna. Podobnie doświadczenia konsumentów związane z funkcjonowaniem poprzedniego przedsiębiorstwa $\mathrm{w}$ danym miejscu mogą być zjawiskiem korzystnym bądź niekorzystnym. Należy zatem dokonać wszechstronnych badań w tej dziedzinie.

Niewątpliwie istotnym czynnikiem wpływającym na lokalizację handlu jest cena dzierżawy lub kupna obiektu handlowego. Wysokie koszty z tym związane mogą spowodować, że dla pewnych branż lub przy określonej wielkości obrotów zlokalizowane w danym miejscu obiekty nie będą rentowne.

Po przeprowadzeniu głębokich analiz detalista dysponuje szczegółowymi informacjami w obszarze handlowym (określeniem obszaru, jego analizą i oszacowaniem popytu) dla wszystkich rozważanych lokalizacji. Ostatni etap procesu decyzyjnego będzie polegał na wyborze konkretnego miejsca/miejsc na nowy obiekt/obiekty (Sullivan, Adcock, 2003).

Często korzysta się przy tym z następujących metod:

- listy kontrolnej,

- analogowej,

- modelowania regresyjnego.

Pierwsza z nich - metoda listy kontrolnej - wymaga zapoznania się z listą obejmującą wszelkie kategorie i rodzaje danych potrzebnych do szczegółowej analizy lokalizacji. Literatura przedmiotu prezentuje wiele kategorii i rodzajów czynników wpływających na ostateczną ocenę lokalizacji. W najbardziej szczegółowej liście (patrz tabela 2) wyróżniono cztery kategorie obejmujące dane o populacji, placówkach detalicznych, kosztach i infrastrukturze.

Metoda analogowa natomiast opiera się na analizie porównawczej z podobnymi sklepami. Wymaga ona zidentyfikowania odpowiednich analogicznych sklepów, ilościowego ujęcia głównych parametrów sklepu na podstawie 
ekstrapolacji wyników uzyskanych przez sklep analogiczny. W początkowej fazie analizy należy zgromadzić dane sondażowe od mieszkańców obszaru otaczającego lokalizację (obiektu porównywanego do naszego), umożliwiające jego klasyfikację na podstawie prawdopodobieństwa wizyty w placówce.

Tabela 2. Lista kontrolna czynników wpływających na atrakcyjność lokalizacji

\begin{tabular}{|c|c|c|c|}
\hline Populacja & Placówki detaliczne & Koszty & Infrastruktura \\
\hline Wielkość i tempo wzrostu & \multirow{2}{*}{$\begin{array}{l}\text { liczba sklepów } \\
\text { (wszystkich, } \\
\text { konkurencyjnych, } \\
\text { komplementarnych) }\end{array}$} & \multirow{4}{*}{$\begin{array}{c}\text { koszty początkowe } \\
\text { obejmujące koszty } \\
\text { zakupu lub dzierżawy, } \\
\text { przygotowania } \\
\text { lokalizacji, budowy } \\
\text { sklepu, uzbrojenia terenu } \\
\text { i koncesji }\end{array}$} & \multirow{2}{*}{$\begin{array}{l}\text { przepływ pieszych } \\
\text { i drogi dojścia }\end{array}$} \\
\hline $\begin{array}{l}\text { Charakterystyka } \\
\text { demograficzna }\end{array}$ & & & \\
\hline $\begin{array}{l}\text { Osobisty dochód } \\
\text { rozporządzalny per capita }\end{array}$ & $\begin{array}{c}\text { wpływ sklepów } \\
\text { komplementarnych na } \\
\text { popyt }\end{array}$ & & \multirow{2}{*}{$\begin{array}{l}\text { rodzaje transportu } \\
\text { publicznego, jego } \\
\text { wygoda i koszty, } \\
\text { połączenia }\end{array}$} \\
\hline $\begin{array}{c}\text { Charakterystyka stylu } \\
\text { życia }\end{array}$ & wnioski o nowe lokalizacje & & \\
\hline Charakter dzielnicy & \multirow{2}{*}{$\begin{array}{c}\text { wpływ sklepów } \\
\text { konkurencyjnych na popyt }\end{array}$} & \multirow{5}{*}{$\begin{array}{c}\text { koszty operacyjne } \\
\text { obejmujące podatki, } \\
\text { konserwację, zapewnianie } \\
\text { bezpieczeństwa, koszty } \\
\text { działalności handlowej } \\
\text { i personelu, koszty utraty } \\
\text { przychodów przez inne } \\
\text { własne placówki }\end{array}$} & dostęp do obiektu dla \\
\hline Schematy zakupów & & & perso \\
\hline Główni pracodawcy & \multirow{3}{*}{ planowane likwidacje } & & widoczność \\
\hline \multirow{2}{*}{ Efekty sezonowe } & & & $\begin{array}{c}\text { sieć drogowa - } \\
\text { zatłoczenie i dostęp }\end{array}$ \\
\hline & & & $\begin{array}{l}\text { pojemność parkingów } \\
\text { i ich dogodne położenie }\end{array}$ \\
\hline
\end{tabular}

Źródło: Sullivan, Adcock, 2003.

Następnie wyróżnia się trzy strefy, dla których prawdopodobieństwo odwiedzenia sklepu jest odpowiednio duże (strefa pierwszorzędna), średnie (strefa drugorzędna) oraz małe (strefa trzeciorzędna). Typowy podział to około $60 \%$ klientów w strefie pierwszorzędnej, 25\% w drugorzędnej i 15\% w trzeciorzędnej. Wartości te mogą się jednak zmieniać w zależności od lokalnego nasilenia konkurencji oraz oferty. Mając te dane, można już przejść do metody analogowej, zakładając, że detalista zidentyfikował potencjalną lokalizację S oraz analogiczny sklep S. W kolejnym kroku należy obliczyć udział sklepu A w całkowitej sprzedaży w każdej ze stref oraz całkowitą sprzedaż tygodniową uzyskiwaną z każdej strefy w przeliczeniu na głowę mieszkańca. Znając wielkość populacji odpowiednich stref otaczających rozważaną lokalizację S, można na podstawie danych sklepu A prognozować tygodniowy popyt generowany przez każdą strefę, a tym samym całkowity popyt na ofertę sklepu w lokalizacji S. Przykład zastosowania tej metody przedstawiono w tabeli 3 . 
Tabela 3. Przykład zastosowania metody analogowej

\begin{tabular}{|l|c|c|c|c|}
\hline \multicolumn{1}{|c|}{ Stefa } & $\begin{array}{c}\text { Udział w sprzedaży } \\
\text { sklepu A } \\
(\%)\end{array}$ & $\begin{array}{c}\text { Sprzedaż per capita } \\
\text { sklepu A } \\
\text { (PLN) }\end{array}$ & $\begin{array}{c}\text { Liczba ludności dla } \\
\text { lokalizacji S } \\
\text { (tys.) }\end{array}$ & $\begin{array}{c}\text { Szacowana } \\
\text { sprzedaż dla } \\
\text { lokalizacji S } \\
\text { (tys. PLN) }\end{array}$ \\
\hline Pierwszorzędna & 62 & 3,35 & 20 & 62,8 \\
\hline Drugorzędna & 22 & 3,15 & 50 & 55,5 \\
\hline Trzeciorzędna & 4 & 2,65 & 90 & 27,0 \\
\hline Razem & & & & 145,4 \\
\hline
\end{tabular}

Źródło: opracowanie własne na podstawie Sullivan, Adcock, 2003.

Wybór lokalizacji z wykorzystaniem metody regresyjnej jest bardziej rygorystycznym postępowaniem i wymaga opracowania modelu ujmującego wyniki sklepu jako funkcję pewnych czynników. Ponieważ wybiera się na ogół kilka takich czynników, należałoby mówić o regresji wielorakiej. Dobór odpowiednich czynników jest niezwykle istotny, zwłaszcza z uwagi na dokładność prognoz, które chce się uzyskać za pomocą otrzymanego modelu.

Zauważyć należy, że funkcjonowanie sieci handlu detalicznego pozostaje pod oddziaływaniem całego splotu czynników społeczno-ekonomicznych i przestrzennych, określanych często mianem czynników sieciotwórczych. Różnorodność czynników, ich wzajemne uwarunkowania i oddziaływania sprawiają, że można dokonać ich klasyfikacji z różnych punktów widzenia (Kałążna-Drewińska, Iwankiewicz-Rak, 1993). W jednej z klasyfikacji podzielono czynniki na:

- kształtujące siłę nabywczą ludności,

- demograficzne,

- wyznaczające efektywność sieci handlowej,

- funkcjonalno-przestrzenne,

- pozostałe czynniki.

Podział ten stanowi punkt odniesienia oceny siły i sposobu oddziaływania poszczególnych czynników na funkcjonowanie istniejącej sieci oraz przewidywanie ich wpływu na sieć programowaną ${ }^{1}$.

1 Szczegółowa charakterystyka omawianych zagadnień została zaprezentowana w: Drewiński, 1983. 


\subsection{LOKALIZACJA ZAKUPÓW W ŚWIETLE BADANIA ANKIETOWEGO}

Badanie ankietowe zostało przeprowadzone w czerwcu 2009 r. i objęło 150 respondentów, a jego celem było poznanie preferencji klientów toruńskich hipermarketów Real i Carrefour odnośnie do miejsca dokonywania zakupów oraz determinant wpływających na wybór badanych obiektów. Problem badawczy został sformułowany przez autorkę artykułu jako następujący: lokalizacja toruńskich hipermarketów Real i Carrefour jako czynnik wpływający na decyzje zakupowe klientów w Toruniu. Populację generalną badania stanowili obecni oraz potencjalni klienci tych hipermarketów. Jednostkę próby stanowił obecny lub potencjalny klient w wieku powyżej 12 roku życia (autorka artykułu uznała - na podstawie własnych obserwacji - iż powyżej tego wieku osoba ma moc decyzyjną w zakresie dokonywania zakupów² ${ }^{2}$. Ze względu na bardzo dużą liczebność badanej populacji, dokonano doboru próby. Autorka artykułu zaproponowała dobór kwotowy, gdyż jest on najlepszą metodą doboru nielosowego, w którym głównym kryterium była płeć respondentów. Badanie wymagało zastosowania metody pomiaru pierwotnego. W celu zebrania danych ze źródeł pierwotnych zastosowano ankietę bezpośrednią jako metodę pomiaru, w której instrumentem pomiaru był kwestionariusz ankietowy.

Charakterystyka badanych respondentów przedstawia się w sposób następujący: płeć - 49,3\% respondentów stanowiły kobiety, mężczyźni - 50,7\%; wiek: poniżej 26 lat $-10,7 \%$ badanych, $26-35$ lat $-30,6 \%$, 36-45 lat $-37,3 \%, 46-55$ lat $-8,7 \%$, powyżej 55 lat $-12,7 \%$; wykształcenie: niepełne podstawowe, podstawowe, gimnazjalne $-1,3 \%$ respondentów, zasadnicze zawodowe $-7,3 \%$, niepełne średnie, średnie, pomaturalne - 37,3\%, licencjat, niepełne wyższe, wyższe - 54,1\%; aktywność zawodowa (możliwość zaznaczenia więcej niż jedną odpowiedź): pracujący(-a) - 65,3\% badanych, uczeń/student $-54,7 \%$, gospodyni domowa $-28,7 \%$, emeryt/rencista $-8,7 \%$, bezrobotny(-a): $-2,6 \%$; liczba osób wspólnie zamieszkujących w gospodarstwie domowym: jedna osoba $-15,3 \%$ respondentów, dwie osoby $-32,7 \%$, trzy osoby $-47,3 \%$, cztery osoby $-4,7 \%$; miesięczny dochód netto na jednego członka gospodarstwa domowego: poniżej 1000 zł - 14,0\% badanych, 1000-1499 zł - 53,3\%, 1500-1999 zł-24,0\%, 2000-2999 zł - 6,0\%, 3000 zł i więcej - 2,7\%.

2 Autorka artykułu zastosowała dobór kwotowy, który pozwala na wybór struktury grupy według subiektywnie wybranych cech ustalonych ex ante, przed doborem próby (o tym, które jednostki znajdą się w próbie decyduje badacz), więcej informacji patrz: Rószkiewicz, 2002. 
W celu poznania preferencji dotyczących miejsc dokonywania zakupów zapytano respondentów, w jakim typie sklepów z największą częstotliwością dokonywali oni zakupów dóbr codziennego użytku. Najczęściej wybieranymi przez respondentów obiektami były supermarkety oraz hipermarkety (patrz wykres 1), w których to aż 70\% ankietowanych dokonywało zakupów.

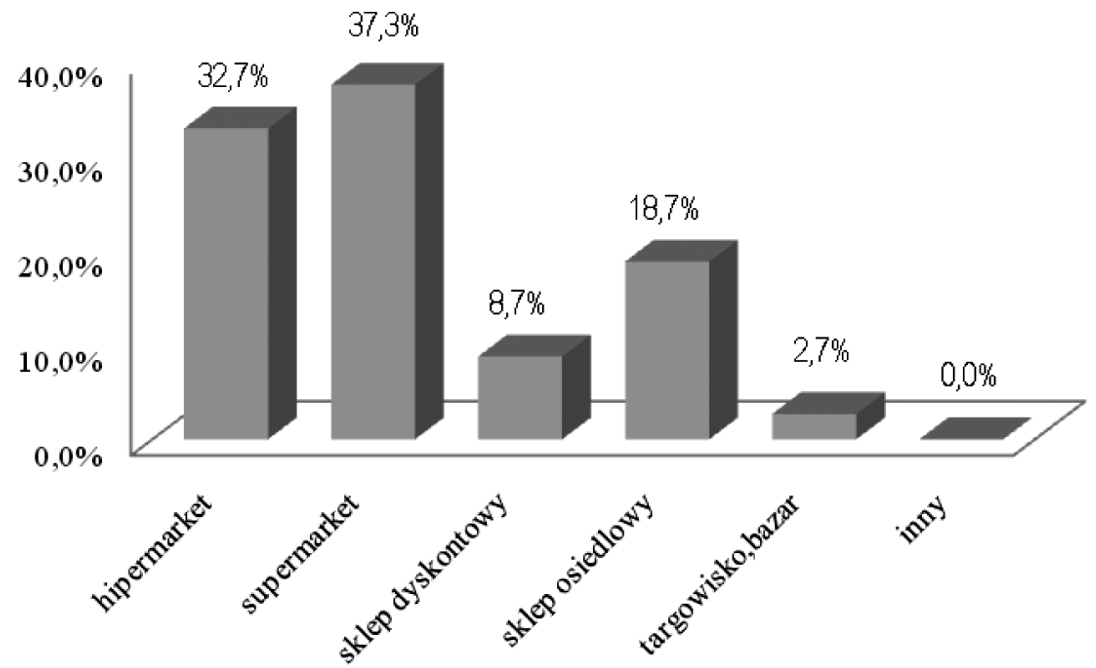

Wykres 1. Typologia sklepów, w których respondenci dokonują zakupów z największą częstotliwością

Źródło: opracowanie własne na podstawie badania ankietowego.

Celem drugiego pytania było poznanie preferencji dotyczących toruńskich hipermarketów Real i Carrefour jako miejsc dokonywania zakupów. Zadowalający ze względu na cel badania był fakt, że aż blisko 93\% respondentów robiło zakupy w badanych hipermarketach. Zdecydowanym liderem, jeżeli chodzi o liczbę respondentów najczęściej wybierających konkretny toruński hipermarket, był Real mieszczący się na ulicy Żółkiewskiego 15, w którym zakupy robiło blisko $49 \%$ respondentów (patrz wykres 2).

Pytanie trzecie umożliwiło poznanie preferencji ankietowanych w zakresie częstotliwości dokonywania zakupów w poszczególnych badanych obiektach. Wyniki odpowiedzi na to pytanie zostały przedstawione na wykresie 3. Zauważyć można, że blisko 44\% respondentów kupujących najczęściej w hipermarkecie Real na ul. Żółkiewskiego 15 preferowało zakupy raz w tygodniu. Z taką samą częstotliwością dokonywali zakupów respondenci preferujący hipermarket Carrefour. Natomiast kilka razy w tygodniu robiło zakupy blisko $43 \%$ ankietowanych preferujących hipermarket Real na ulicy Grudziądzkiej 162. 


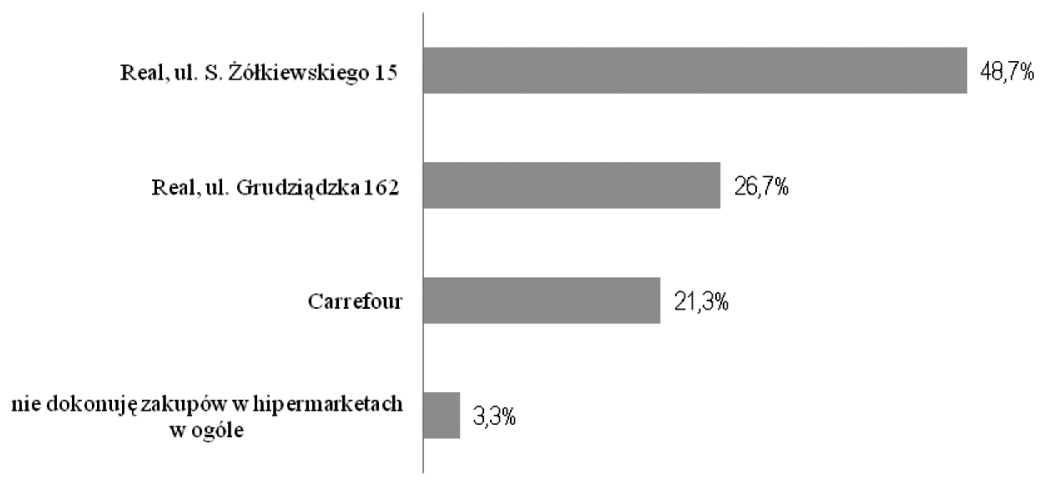

Wykres 2. Preferencje respondentów dotyczące toruńskich hipermarketów Real i Carrefour jako miejsc dokonywania zakupów

Źródło: opracowanie własne na podstawie badania ankietowego.

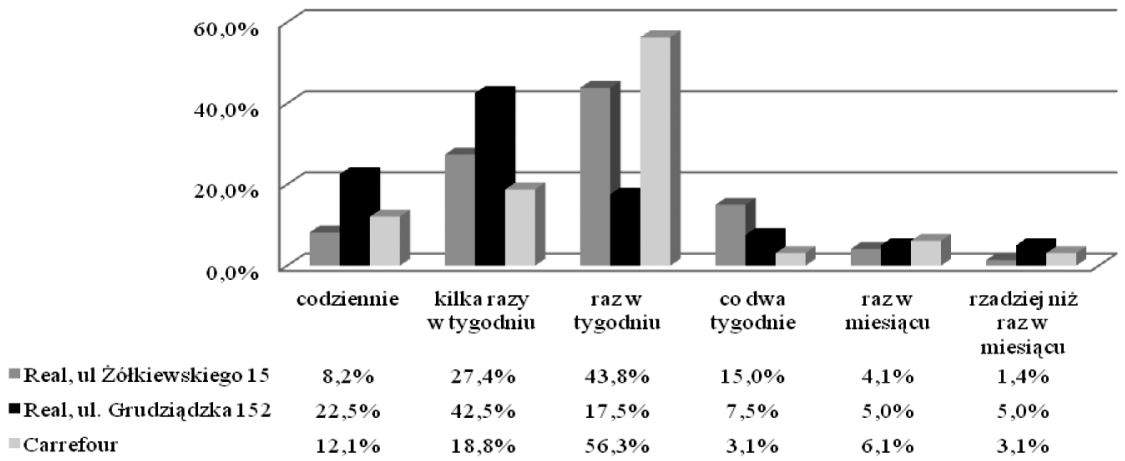

Wykres 3. Częstotliwość dokonywania zakupów w toruńskich hipermarketach Real i Carrefour

Źródło: opracowanie własne na podstawie badania ankietowego.

W kolejnym pytaniu respondenci zostali poproszeni o wskazanie środka transportu, za pomocą którego najczęściej docierali do badanych obiektów handlowych. Najczęściej wskazywaną odpowiedzią (patrz wykres 4) przez ankietowanych preferujących hipermarket Real na ulicy Żółkiewskiego 15 było połączenie miejskimi środkami transportu - blisko $47 \%$ ankietowanych w ten sposób docierało do obiektu. Badani preferujący drugi z hipermarketów Real najczęściej dostawali się do sklepu pieszo - takiej odpowiedzi udzieliło 40\% respondentów. Najczęściej wykorzystywanymi środkami transportu przez ankietowanych preferujących Carrefour były samochody - blisko 66\% ankietowanych wskazało tę odpowiedź. 


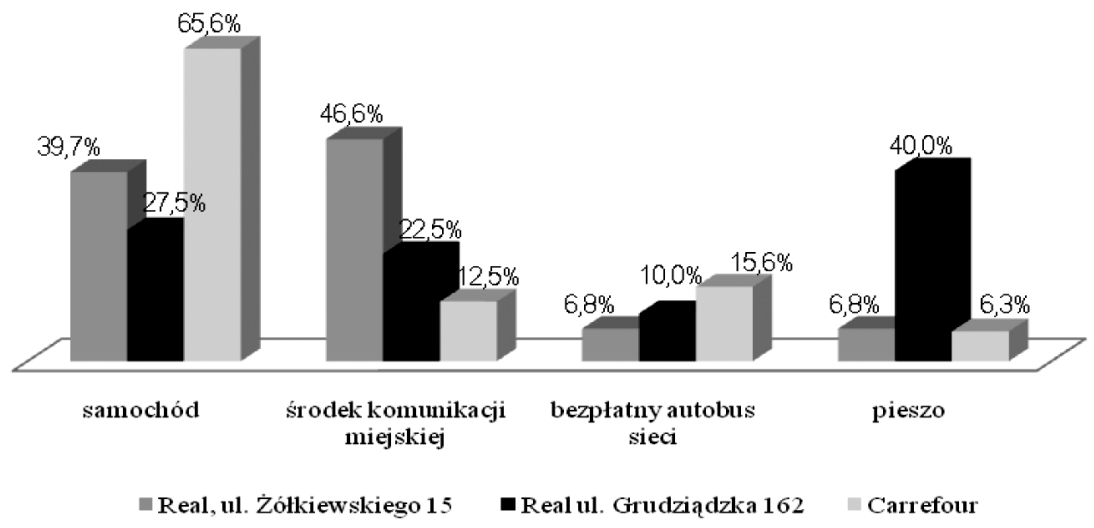

Wykres 4. Wykorzystanie środków transportu w celu dotarcia do badanego hipermarketu Źródło: opracowanie własne na podstawie badania ankietowego.

Respondenci zostali poproszeni również o określenie odległości dzielącej ich miejsce zamieszkania od konkretnego hipermarketu (patrz wykres 5).

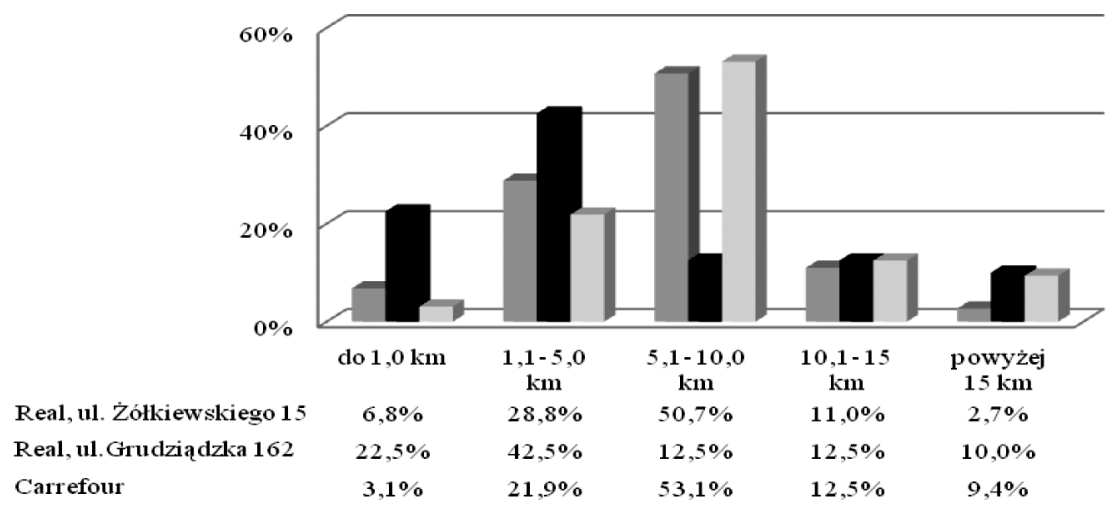

Wykres 5. Struktura pokonanej odległości przez respondentów między miejscami ich zamieszkania a wybranym hipermarketem

Źródło: opracowanie własne na podstawie badania ankietowego.

$\mathrm{Na}$ podstawie odpowiedzi dotyczących odległości między miejscem zamieszkania a hipermarketem można stwierdzić, że respondenci byli skłonni do pokonywania nawet znacznego dystansu w celu dokonania zakupów. Może być to wynikiem wielu czynników, jak chociażby chęci pozyskania dóbr w niższej cenie, czy też robienia zakupów rzadziej, ale w większej ilości w miejscu, gdzie jest większy wybór towarów. 
Niezwykle istotne ze względu na możliwości rozwiązania problemu badawczego były odpowiedzi respondentów określające determinanty wyboru badanych hipermarketów jako miejsc dokonywania zakupów (patrz tabela 4). Badaniu zostały poddane następujące czynniki:

- dogodna lokalizacja badanych hipermarketów,

- przystępna cena oferowanych produktów w badanych obiektach,

- wysoka jakość obsługi klienta,

- różnorodność oferowanego asortymentu,

- dogodne godziny otwarcia,

- dostęp do wielu usług w jednym budynku.

Tabela 4. Struktura determinant wpływających na wybór toruńskich hipermarketów Real i Carrefour jako miejsc dokonywania zakupów

\begin{tabular}{|c|c|c|c|c|}
\hline \multirow{2}{*}{ Obiekt } & \multicolumn{4}{|c|}{ Ważność czynnika (\%) } \\
\hline & Bardzo ważny & Raczej ważny & Mało ważny & Bez znaczenia \\
\hline \multicolumn{5}{|c|}{ dogodna lokalizacja hipermarketu } \\
\hline Real, ul. Żółkiewskiego 15 & 53,4 & 30,1 & 11 & 5,5 \\
\hline Real, ul. Grudziądzka 162 & 67,5 & 22,5 & 10 & 2,5 \\
\hline Carrefour & 31,3 & 25 & 34,4 & 9,4 \\
\hline \multicolumn{5}{|c|}{ przystępna cena oferowanych produktów } \\
\hline Real, ul. Żółkiewskiego 15 & 31,5 & 21,9 & 27,4 & 19,2 \\
\hline Real, ul. Grudziądzka 162 & 47,5 & 35,0 & 15,0 & 2,5 \\
\hline Carrefour & 40,6 & 28,1 & 18,8 & 12,5 \\
\hline \multicolumn{5}{|c|}{ wysoka jakość obsługi klienta } \\
\hline Real, ul. Żółkiewskiego 15 & 2,7 & 11,0 & 19,2 & 67,2 \\
\hline Real, ul. Grudziądzka 162 & 0,0 & 1,0 & 40,0 & 59,0 \\
\hline Carrefour & 0,0 & 6,3 & 21,9 & 71,8 \\
\hline \multicolumn{5}{|c|}{ różnorodność oferowanego asortymentu } \\
\hline Real, ul. Żółkiewskiego 15 & 4,1 & 19,2 & 58,9 & 17,8 \\
\hline Real, ul. Grudziądzka 162 & 27,5 & 42,5 & 22,5 & 7,5 \\
\hline Carrefour & 21,9 & 40,6 & 31,3 & 6,3 \\
\hline \multicolumn{5}{|c|}{ dogodne godziny otwarcia } \\
\hline Real, ul. Żółkiewskiego 15 & 32,9 & 19,2 & 13,1 & 34,8 \\
\hline Real, ul. Grudziądzka 162 & 17,5 & 20,0 & 15,0 & 45,0 \\
\hline Carrefour & 46,9 & 25,0 & 12,5 & 15,6 \\
\hline \multicolumn{5}{|c|}{ dostęp do wielu usług w jednym budynku } \\
\hline Real, ul. Żółkiewskiego 15 & 64,4 & 20,5 & 9,6 & 5,5 \\
\hline Real, ul. Grudziądzka 162 & 17,5 & 10,0 & 50,0 & 22,5 \\
\hline Carrefour & 21,9 & 53,1 & 25,0 & 0,0 \\
\hline
\end{tabular}

Źródło: opracowanie własne na podstawie badania ankietowego. 
Opinie dotyczące czynników, które miały wpływ na decyzje o wyborze konkretnego obiektu handlowego na miejsce realizacji zakupów, pozwoliły na dokonanie hierarchizacji badanych determinant (wraz z procentowym udziałem respondentów, dla których czynnik ten jest co najmniej raczej ważny przedstawiona została na wykresie 6):

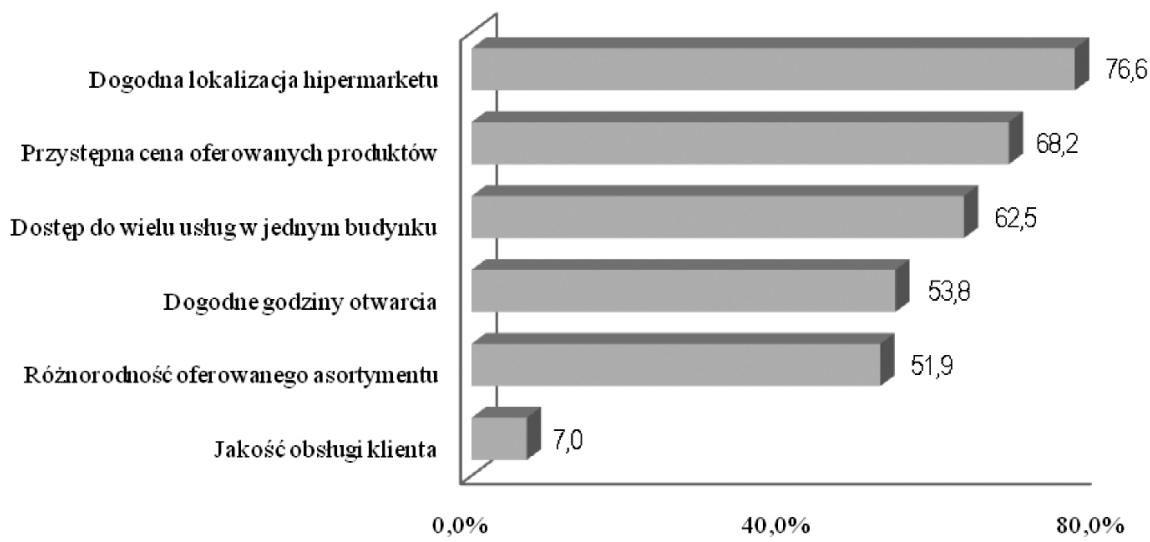

Wykres 6. Determinanty wyboru hipermarketów na miejsce realizacji zakupów

Źródło: opracowanie własne na podstawie badania ankietowego.

Warto przyjrzeć się bliżej najważniejszemu w opinii respondentów czynnikowi - dogodnej lokalizacji. Lokalizacja hipermarketu Real mieszczącego się przy ulicy Żółkiewskiego 15 w Toruniu była bardzo ważnym czynnikiem wpływającym na decyzje o wyborze właśnie tego obiektu jako miejsca dokonywania zakupów dla ponad 53\% respondentów. Jako raczej ważny czynnik ten został określony przez ponad 30\% ankietowanych i jako mało ważny oraz bez znaczenia, odpowiednio, przez $11 \%$ i blisko $6 \%$ badanych. Natomiast lokalizacja drugiego $\mathrm{z}$ hipermarketów Real (jako bardzo istotna $\mathrm{w}$ procesie podejmowania decyzji) została określona jako bardzo ważna przez blisko $68 \%$ ankietowanych, raczej ważna przez blisko $23 \%$, mało ważna przez $10 \%$ i bez znaczenia zaledwie przez $2,5 \%$ badanych. To właśnie respondenci tego hipermarketu cenili lokalizację najbardziej wśród pozostałych ankietowanych. Respondenci robiący zakupy w hipermarkecie Carrefour przywiązywali mniejszą uwagę do lokalizacji w porównaniu z respondentami robiącymi zakupy w hipermarketach Real, ale w dalszym ciągu dla ponad $31 \%$ ankietowanych lokalizacja była bardzo ważnym czynnikiem, dla $25 \%$ raczej ważnym, dla ponad $34 \%$ mało ważnym oraz bez znaczenia dla ponad 9\% badanych. Znając już stopień ważności najbardziej istotnego ze względu na cel badania czynnika, warto zapoznać się z opiniami respondentów dotyczącymi badanych hipermarketów. 
Respondenci zostali poproszeni o ocenę obiektów pod względem następujących czynników:

- dogodna lokalizacja hipermarketu,

- dostępność połączeń komunikacji miejskiej,

- dostępność połączeń bezpłatną linią autobusową sieci,

- dostępność miejsc parkingowych przy obiekcie.

Odpowiedzi na to pytanie zostały zliczone i przedstawione w tabeli 5.

Lokalizacja hipermarketu Real mieszczącego się na ul. Żółkiewskiego 15 w Toruniu została oceniona bardzo dobrze przez ponad $67 \%$ respondentów robiących najczęściej zakupy w tym obiekcie, a jako raczej dobra przez ponad 19\%. Blisko 7\% ankietowanych nie potrafiło jednoznacznie ocenić hipermarketu pod tym względem, a ponad $5 \%$ oceniło obecną lokalizację jako niedobrą i ponad $1 \%$ jako bardzo niedobrą. Respondenci dokonujący zakupów w hipermarkecie Real na ul. Grudziądzkiej 162 w Toruniu ocenili pozytywnie lokalizację tego obiektu - żaden z respondentów nie ocenia negatywnie jego położenia. Bardzo dobrze lokalizacja hipermarketu została oceniona przez 55\% badanych, raczej dobrze przez blisko $38 \%$, a niejednoznacznie przez blisko $8 \%$ ankietowanych.

Tabela 5. Struktura ocen hipermarketów Real i Carrefour pod względem wybranych czynników

\begin{tabular}{|l|c|c|c|c|c|}
\hline \multirow{2}{*}{ Obiekt } & \multicolumn{5}{c|}{ Ocena (\%) } \\
\cline { 2 - 6 } & Bardzo dobra & Raczej dobra & Ani dobra ani zła & Niedobra & b. niedobra \\
\hline \multicolumn{5}{|c|}{ dogodna lokalizacja hipermarketu } \\
\hline Real, ul. Żółkiewskiego 15 & 67,1 & 19,2 & 6,8 & 5,5 & 1,4 \\
\hline Real, ul. Grudziądzka 162 & 55,0 & 37,5 & 7,5 & 0,0 & 0,0 \\
\hline Carrefour & 40,6 & 28,1 & 18,75 & 6,25 & 6,3 \\
\hline \multicolumn{7}{|c|}{ dostępność połączeń komunikacji miejskiej } \\
\hline Real, ul. Żółkiewskiego 15 & 31,5 & 56,2 & 5,5 & 6,8 & 0,0 \\
\hline Real, ul. Grudziądzka 162 & 47,5 & 40,0 & 5,0 & 5,0 & 2,5 \\
\hline Carrefour & 15,6 & 37,5 & 25,0 & 9,4 & 12,5 \\
\hline \multicolumn{7}{|c|}{ dostępność połączeń bezpłatną linią autobusową sieci } \\
\hline Real, ul. Żółkiewskiego 15 & 0,0 & 19,2 & 58,9 & 21,9 & 0,0 \\
\hline Real, ul. Grudziądzka 162 & 10 & 0,0 & 20,0 & 70,0 & 0,0 \\
\hline Carrefour & 12,1 & 27,3 & 42,4 & 18,2 & 0,0 \\
\hline \multicolumn{7}{|c|}{ dostępność miejsc parkingowych przy obiekcie } \\
\hline Real, ul. Żółkiewskiego 15 & 37 & 53,4 & 9,6 & 0,0 & 0,0 \\
\hline Real, ul. Grudziądzka 162 & 0,0 & 20,0 & 60,0 & 20,0 & 0,0 \\
\hline Carrefour & 36,4 & 48,5 & 15,2 & 0,0 & 0,0 \\
\hline
\end{tabular}

Źródło: opracowanie własne na podstawie badania ankietowego. 
Natomiast lokalizacja hipermarketu Carrefour jako bardzo dobra została oceniona przez ponad $40 \%$ respondentów, a jako raczej dobra przez ponad $28 \%$. Blisko $19 \%$ ankietowanych nie potrafiło jednoznacznie ocenić położenia obiektu. Dla ponad $6 \%$ badanych lokalizacja jest niedogodna i dla ponad $1 \%$ bardzo niedogodna.

Niezwykle istotne było również poznanie determinant, które powstrzymywały respondentów od dokonywania zakupów w hipermarketach. Rozkład tych czynników przedstawia się następująco (1 - czynnik najważniejszy, 5 - czynnik najmniej ważny):

- niedogodna lokalizacja,

- niedogodne połączenia komunikacją miejską,

- niedogodne połączenia bezpłatnym autobusem sieci,

- niska jakość produktów,

- niska jakość obsługi klienta.

$\mathrm{Na}$ decyzje respondentów w tym zakresie nie wywierała wpływu cena oferowanych produktów (była ona postrzegana jako przystępna, więc nie wpływała niekorzystnie) oraz dostępność miejsc parkingowych przy obiektach (która była oceniana pozytywnie).

Respondenci, którzy nie robią zakupów w hipermarketach w ogóle, musieliby poświęcić od 31 do 60 minut w celu dotarcia do najbliższego takiego obiektu w ich miejscu zamieszkania, co stanowiło dla nich zbyt długi przedział czasowy.

\section{PODSUMOWANIE}

Wśród wszystkich problemów natury ekonomicznej i organizacyjnej związanych z kształtowaniem sieci handlowej największe znaczenie ma lokalizacja. Im dogodniejsze umiejscowienie obiektu handlowego w przestrzeni, tym większa szansa na odniesienie sukcesu w działalności. Niewątpliwie sukces na rynku polskim odnoszą obiekty wielkopowierzchniowe, które cieszą się dużym zainteresowaniem klientów $-70 \%$ badanych respondentów wskazuje hipermarkety jako najczęstsze miejsce dokonywania zakupów. Zauważyć należy, że to właśnie lokalizacja obiektu stanowi najważniejszą kwestię determinującą wybór miejsca zakupów przez klientów. Nasuwa się stwierdzenie, że współczesny konsument oczekuje, iż w jednym dogodnie położonym obiekcie zaspokoi swoje potrzeby konsumenckie po przystępnych cenach i w odpowiednim dla siebie czasie. Chcąc być znaczącym na rynku graczem w walce o klienta, handlowcy powinni więc wychodzić naprzeciw oczekiwaniom konsumentów umiejscawiając swoje obiekty w odpowiedniej przestrzeni z korzystną ofertą handlową. 


\section{LITERATURA}

Drewiński M. (1983), Programowanie sieci handlu i ustug, Wydawnictwo Uczelniane Akademii Ekonomicznej we Wrocławiu, Wrocław.

Kałążna-Drewińska U., Iwankiewicz-Rak B. (1993), Organizacja i technika handlu, Wydawnictwo Akademii Ekonomicznej we Wrocławiu, Wrocław.

Knee D., Waters D. (1985), Strategy in retailing. Theory and application, The Oxford Centre for Management Studies, Oxford.

Rószkiewicz M. (2002), Metody ilościowe w badaniach marketingowych, Wydawnictwo Naukowe PWN, Warszawa.

Sławińska M. (1989), Sieć handlowa [w:] Z. Zakrzewski, red., Ekonomika handlu wewnętrznego, PWE, Warszawa.

Sullivan M., Adcock D. (2003), Marketing w handlu detalicznym, Oficyna Ekonomiczna, Kraków.

Szulce H. (1998), Struktury i strategie w handlu, PWE, Warszawa.

\section{LOCATION AS A FACTOR DETERMINING CUSTOMERS' BUING DECISIONS BASED ON AN EXAMPLE OF REAL AND CARREFOUR HYPERMARKETS IN TORUŃ}

A bstract: An article features selected aspects concerning strategy of location when establishing a shopping centre. There has been described an essence and tools of location. The author indicates that location determinates customers' buying decisions and publishes the result of survey about factors which influence customers' buying decisions.

K e y w o r d s : location, customers' buying decisions, hypermarkets. 